\author{
Gintarè Pavilavičiūtè \\ Vytautas Magnus University, Lithuania
}

\title{
TRANSLATION AS A BARRIER BETWEEN THE ORIGINAL NARRATIVE AND THE READER: A CASE STUDY OF POWER RELATIONS AND ADDRESS FORMS IN TWO CRIME FICTION NOVELS
}

Summary. The role of the translator as a mediator in literary translation has been a salient topic since the late twentieth century; however, more recent research signifies that instead of mediating, the translator sometimes affects the literary work translated, shifting the focus of such studies onto the reader. This article aims at investigating the possible effects the literary translator has on readers by examining the translation of address forms, the linguistic markers of social status into Lithuanian and the use of polite or familiar second-person pronouns in two crime fiction novels, Agatha Christie's (1962) The Mirror Crack'd from Side to Side and John Grisham's (1992) The Pelican Brief. The literary translator may grapple with the issue of translating social interactions which derives from cultural differences present in the source and target societies. Subsequently, containing a plethora of realistically depicted social interactions adherent to the societies represented, crime fiction provides Lithuanian literary translators with the issue of deciphering power relations based on the contexts they occur in and choosing accordant polite or familiar second-person pronouns, a distinction not present in English. As this study has shown, the translator sometimes misinterprets power relations or favours the social norms of the target culture, affecting the narrative, creating effects discordant with the writer's intentions, and in some cases, entailing a contingent barrier between the reader and the original literary work.

Keywords: power relations; address forms; literary translation; translation effects; barrier.

\section{Introduction}

Until the 1980s, when translation studies became a discipline on its own, translators were seen as invisible, especially in the Anglo-American world (Venuti, 1995). Such invisibility stemmed from fluent renditions of source texts (ST), the target texts (TT). Since the mid-1990s, after the publication of Venuti's (1995) The Translator's Invisibility, there has been a debate on the (in) visibility and influence of the translator in literary translation. In the past few decades, translators have become more apparent both in the AngloAmerican world and world-wide, as many studies, focusing on the role of 
the translator as a mediator have shown (Nunez, 2012; Shirinzadeh and Mahadib, 2015). Currently, there is a growing number of studies indicating not only the mediation but also the interference of the translator in literary texts (Boyden, 2014; Khakimova, 2017).

There are studies envisaging the invisibility of the translator as not only a means to close the breach between one culture and the other. As Sabine Strümper-Krobb (2003) puts it, 'the translator's invisibility, for instance, has been revealed as a cover-up for significant interferences in the translated texts and the translator has been shown to be caught up in the power struggle between cultures' (p. 116). Yet the problem of the power struggle between cultures is encoded in the existence of the translator itself. Because readers have no direct contact with the foreign writer if they are not fluent in the language of the original text, there is a demand for translation. Ideally, it is the translator's role to overcome 'linguistic and cultural barriers separating a sender and a receiver who belong to substantially different worlds' (Nunez, 2012 , p. 27). The present study, however, concentrates on how the literary translator sometimes creates these barriers, alienating the reader from the original message the writer sends.

By hypothesising about the position of the reader, this study aims to examine the way the translator affects the $\Pi T$ with regards to translation of address forms. The main interest in this paper is to investigate the effects the translator creates, which is achieved by the analysis of social interactions in two crime novels, Agatha Christie's (1962) The Mirror Crack'd from Side to Side and John Grisham's (1992) The Pelican Brief, and their Lithuanian counterparts Perskilęs Veidrodis (Kirvaitytè, 2000) and Pelikano Dosjè (Čeponis, 2004). The choice of crime fiction is not random: attention has already been drawn on the inadequacies in the translation of culture specific items in crime novels of the mid and late-twentieth century into Lithuanian (Drazdauskienè, 2016).

Address forms, the linguistic markers of social status, used to express power relations in social interactions are chosen as the object of analysis, as they are often different across cultures and may pose difficulties for literary translators. The main problem for Lithuanian translators is to match address forms with polite or familiar second-person pronouns, known as the T/V distinction. The abbreviation T/V refers to the distinction of the second-person pronouns tu (singular/familiar) and vous (plural/polite) in French (Brown and 
Gilman, 1960). Whereas power relations in literary texts are abundantly researched by English specialists (Anderman, 1993; Ermida, 2006), in Lithuanian there is a lack thereof. This is especially pertinent considering the number of English literary texts that are being translated into Lithuanian. Studies regarding power relations, address forms, and second-person pronouns in the field of literary translation are relatively few (Dziedravičiūtè, 2009). Hence, this study adds to the research in the field of literary translation in Lithuania, offering emphasis on the effect the translator creates in the narrative rather than analysing the translation strategies used, as is the case in Dziedravičiūtè's (2009) study. Considering both the abundance of translated literature appearing in Lithuanian book-stores and having a vast number of readers, as well as the commentaries on the rather low quality of some translations, especially of the crime fiction genre (see Drazdauskienè, 2016), this study also attempts to raise a discussion about the issues of translation quality.

\section{A Brief Overview of Sociolinguistic Markers of Social Status}

Murray Millner (2010) defines social status as 'the distinctions of rank or stature attributed to a person, group, idea, or object' (p. 295). A person's status depends on the expression of approval or disapproval by other members of society, making status a relational concept. Writing on social status in modern society, Cecilia L. Ridgeway (2014) emphasises that social status is a product of others' subjective evaluation of and beliefs about the social behaviour of a particular group. Nevertheless, deliberate display of status can militate against this evaluation. According to Tak Wing Chan and John H. Goldthorpe (2010), 'to signal status is to lay claim to group membership: to whom one has affiliations, and from whom is one different' (p. 1105). Through signalling status people coax the beliefs held about them, distinguish themselves from others, thus classifying oneself and others as belonging to certain status groups.

In order to signal affiliations or differences in status groups, one can use sociolinguistic markers, address forms and polite or familiar (T/V) secondperson pronouns, as these can help assert power, express solidarity or 
maintain social distance, as explained by Keith Allan and Kate Burridge (2006). There is a variety of address forms to choose from in English based on the relationships between speakers and listeners: 'by first name (Mary), by title and last name (Ms A, Mr B, Dr C), by some kind of deferential form (sir, ma'am)' (Thornborrow, 2004, p. 162). Xiaomei Yang (2010, p. 743) lists the following titles that are used without names for more formality and social distance: kinship and occupational titles, titles of rank, honorifics, and zero use for neutrality.

Studies on the T/V distinction found in many European languages are often based on the theoretical model presented by Roger Brown and Albert Gilman (1960), who focused on the T/V distinction as representing 'familiar' and 'polite' forms in European languages. Drawing on Brown and Gilman, Manuela Cook (2014) states that 'whilst solidarity tends to result in reciprocal $\mathrm{T}$ or $\mathrm{V}$, power will determine a non-reciprocal interaction in which the superior says $T$ but may expect to receive $V^{\prime}$ (p. 17). An asymmetric use of T/V marks inequality and distance between the participants in an interaction; a symmetric use signals that the participants are of the same status or are in a close relationship.

Lithuanian distinguishes between the plural and singular you as 'familiar' and 'polite' forms. Laura Čubajevaitè (2006) indicates that 'there is a distinction between a formal and informal way of addressing other people, that is, there are two forms of the second-person pronoun: $t u$ and jūs' (p. 3334). She states that the use of these pronouns signals 'intimacy, solidarity, respect, power and authority' (Čubajevaitè, 2006, p. 34). Overall, in Lithuanian there has been a change in address forms and the use of polite and familiar pronouns throughout the years. In 1988-1992, most common address forms were the formal '(first name / comrade / honourable / Sir / position) + last name' and the less formal '(honourable / Sir) + first name' (Girčienè, 2011, p. 8). The period of 1993-2011 saw a great shift to informality: communication on first name basis and the use of the familiar tu became widespread. The three most common types of address forms in this period were the formal '(first name / Sir / honourable / formal position) + last name [plural f. Jūs], (Sir / honourable / dear) + first name [plural f. Jūs]' and the informal '(dear) + first name [singular f. Tu]' (Girčienè, 2011, p. 8). Still, in the late 1990s older 
men preferred polite forms and pronouns when addressing women, both acquainted and not (Rosinas, 1996, p. 38).

Cook (2014, p. 18) indicates that the English you is neutral, allowing the reduction of inequality between the participants in an interaction. Despite that, the T/V distinction found in other languages, according to Gunilla M. Anderman (1993), is very useful in a number of ways, especially in literary writings:

As the use of $V$ is normally associated with power, a simple change to $T$ can easily be used to signal increased subservience. And on another level such a switch may also indicate a higher degree of intimacy and emotional commitment. The introduction of $\mathrm{V}$ on the other hand into the interaction between interlocutors of equal standing may show precisely with whom, in a given situation, the power rests. It would also, on the level of intimacy, tell us of sudden withdrawal and feelings of remoteness (p. 59).

To Anderman, the T/V distinction not only indicates who has power over whom but also shows the subtleties of the participants' relationships. The neutral you in English poses a problem for Lithuanian literary translators since social relations in English are encoded using subtler linguistic or non-linguistic means, sometimes creating difficulties in deciding on polite or familiar second-person pronouns.

\section{Data, Methodology and Limitations}

Regarding limitations, the major one in this research is the scope of analysis: this study is limited by the number of books chosen. Although only two English novels and their translations are selected, they contain numerous instances of complex and varied social interactions in contexts that may still be unfamiliar in the Lithuanian culture. As part of the crime fiction genre, Christie's The Mirror Crack'd from Side to Side and Grisham's The Pelican Brief, provide a great deal of rich and realistic depiction of two specific societies, British and American, with their class structures and social relations, as these are crucial for solving the crime. Both novels portray society in transition: from rigid social norms to more informality in Christie's case and from informality in governmental 
institutions to moral decay in Grisham's, which involves changes in social interactions and subtle use of address forms to signal social status and power relations.

Not recent, these novels still presented the translators, Rasa Kirvaityte and Jonas Čeponis, with the task to transfer the writers' intentions to show the realities of social interactions among members of different status in their respective societies in the second half of the twentieth century. Being translated at least a decade after their publication, these novels depict societies different from the translators' own, often denying the translators the possibility to base social interactions in the ST on social norms present in the temporal society of the reader and the translator. The translation of older novels suggests that there may nonetheless be some cases and contexts in literature miscommunicated to the reader even now if not translated with a great amount of consideration and research. This leads to another limitation: the manner of analysis in regard to translation processes and choices in this research is speculative. This is due to the opacity of the translators' work process and decision making, as personal commentaries on translation choices made are rarely available in Lithuanian publications.

As a methodological approach, this study uses comparative qualitative analysis of address forms and second-person pronouns used with them. At first, each address form is collected manually to observe the context in which it occurs and the second-person pronoun used with it in the ST and TT to see whether the language used by characters in high social positions agrees with their social status. The number of types of address forms in Christie's English novel is 75 and 85 in its Lithuanian translation, while in Grisham's English novel and its translation the number is 73 . The total number of address forms in Christie's novel is 272 and 270 in its Lithuanian variant; in Grisham's English novel address forms occur 398 times in total and 397 times in its Lithuanian translation. These figures indicate the translators' attempt at a very high level of faithfulness to the STs.

After considering the theoretical framework on address forms and observing the data, a typology has been created for this study. Here, the type of relationships between speakers is the most significant, as those define the choice of address forms. Concerning the Lithuanian variants of the English novels, each instance of address forms is checked manually to identify the type 
of second-person pronouns matched with them. The full typology can be seen in Table 1 below:

Table 1.

The typology for examining social interactions in ST and TT

\begin{tabular}{|c|c|c|c|c|c|c|}
\hline 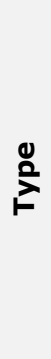 & 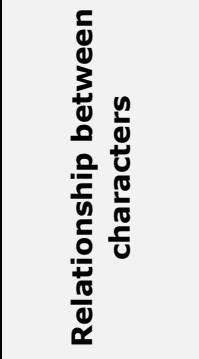 & 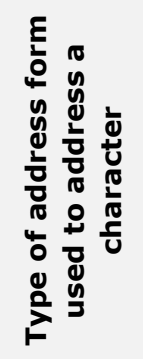 & 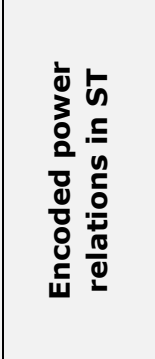 & 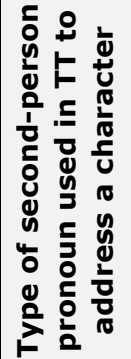 & 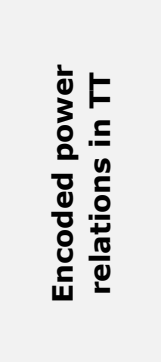 & 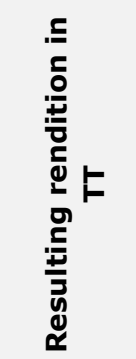 \\
\hline 1 & Intimate & Informal & Solidarity & Familiar & Solidarity & Faithful \\
\hline 2 & Intimate & Informal & Solidarity & Polite & $\begin{array}{c}\text { Solidarity/ } \\
\text { distance }\end{array}$ & $\begin{array}{c}\text { Requires } \\
\text { analysis }\end{array}$ \\
\hline 3 & Intimate & Formal & Distance & Polite & Distance & Faithful \\
\hline 4 & Intimate & Formal & Distance & Familiar & Solidarity & $\begin{array}{l}\text { Requires } \\
\text { analysis }\end{array}$ \\
\hline 5 & $\begin{array}{c}\text { Professional/ } \\
\text { intimate }\end{array}$ & Informal & Solidarity & Familiar & Solidarity & Faithful \\
\hline 6 & $\begin{array}{c}\text { Professional/ } \\
\text { intimate }\end{array}$ & Informal & Solidarity & Polite & $\begin{array}{c}\text { Solidarity/ } \\
\text { distance }\end{array}$ & $\begin{array}{l}\text { Requires } \\
\text { analysis }\end{array}$ \\
\hline 7 & $\begin{array}{c}\text { Professional/ } \\
\text { intimate }\end{array}$ & Formal & Distance & Polite & Distance & Faithful \\
\hline 8 & $\begin{array}{c}\text { Professional/ } \\
\text { intimate }\end{array}$ & Formal & Distance & Familiar & $\begin{array}{c}\text { Solidarity/ } \\
\text { distance }\end{array}$ & $\begin{array}{l}\text { Requires } \\
\text { analysis }\end{array}$ \\
\hline 9 & Professional & Formal & Distance & Polite & Distance & Faithful \\
\hline 10 & Professional & Formal & Distance & Familiar & $\begin{array}{c}\text { Asserting } \\
\text { power }\end{array}$ & $\begin{array}{c}\text { Requires } \\
\text { analysis }\end{array}$ \\
\hline 11 & Professional & Informal & $\begin{array}{l}\text { Asserting } \\
\text { power }\end{array}$ & Polite & Distance & $\begin{array}{c}\text { Requires } \\
\text { analysis }\end{array}$ \\
\hline 12 & Professional & Informal & $\begin{array}{l}\text { Asserting } \\
\text { power }\end{array}$ & Familiar & $\begin{array}{c}\text { Asserting } \\
\text { power }\end{array}$ & Faithful \\
\hline
\end{tabular}

As an addition to this typology, neutral zero use instances of address forms are always examined in their respective contexts. In the typology, three types of relationships between characters are identified: intimate, professional, and a combination of two, when characters are close but also engage in professional interactions. When informal types of address such as first names or pet names are matched with the familiar second-person singular pronoun or formal types of address such as titles and last names are matched with 
the polite second-person plural pronoun, the translation is considered to be faithful, as the social interactions conform to the norms of social interactions typical to the relationship present between characters. When there is a discrepancy, the exchange is examined in more detail, considering the context in which it occurs, for example the characters' occupation, age and body language. When address forms, second-person pronouns and the context do not match, the exchange is deemed problematic or requiring further analysis and discussed in detail.

\section{Results and Discussion}

Since translation is a subjective process, the majority of the translators' choices are personal ones based on their beliefs and the information known about the context of the novels translated and the cultures they originate from. Done a decade after the publication of Grisham's original novel in 1992, Čeponis's translation seems to aim at the depiction of a more formal society that does not accord with the reality of the United States in the 1990s, with its informal communication in professional situations and corruption at the institutional level and within the ranks of the leaders (Danytè, 2012, p. 23). Albeit done forty years after the publication of Christie's novel in 1962, Kirvaitytè captures the strict formality of interactions, which could stem from commonly held beliefs about rigid class distinction in British society of the mid-twentieth century (Robson, 2016). However, Christie intended to portray the decline of such rigidity with the gradual transition into a more informal society, which requires the translator to be especially careful when dealing with linguistic subtleties.

As a genre, crime fiction provides a rich and often realistic depiction of specific societies and their class structures and social relations, often defined by characters' occupation, as well as a relatively difficult task for literary translators to render these sociocultural elements to their own cultures. Golden Age crime fiction like Christie's The Mirror Crack'd from Side to Side focuses on social realism and the upper-middle class. Golden Age novels are 'dense with details about villages and houses, furniture, clothing, meals, social structures and the like', while the characters are 'sharply defined by their use of language, 
choice of clothes and social mannerisms' (Danytè, 2011, p. 13-17). In The Mirror Crack'd from Side to Side, the British society of the mid-twentieth century includes elements from both the old rural world and the new modern one: the old village of St Mary Mead and a new suburb called the Development. These are connected by a murder solved by Miss Marple, an elderly resident of the village who, unlike others from her age group, accepts the inevitable social changes.

Like the whole thriller sub-genre, legal thrillers such as Grisham's The Pelican Brief are concerned with corrupt societies (Danytè, 2011, p. 34). These thrillers 'tend to be connected to the political beliefs and concerns of the period in which they are written' and are 'often researched and fairly reliable' (Danytè, 2011, p. 36-37). As an example, The Pelican Brief portrays the highest ranks of the United States political circle and their involvement in the assassination of Supreme Court justices and an ecological crime, both solved by a law student, Darby Shaw, and a reporter, Gray Grantham. Overall, both sub-genres target realistic representation of high society in a particular period of time, making them good sources of varied linguistic interactions with shifting power relations among characters.

Christie's novel depicts British society in transition from strict social norms to less formality in conversation. Many characters, especially older ones, maintain those strict norms and social distance, entailing symmetric exchanges of polite address forms. This allows the translator to add Lithuanian polite second-person pronouns more intuitively without overanalysing the social contexts and relationships present in each conversation. In the original novel, there are instances where the use of address forms is asymmetric, which actually signals one character's higher status over the other's, or an attempt to assert power (see example 1).

1. Miss Knight: 'Well, I don't like to leave you too long on your own, dear, in case you get moped'.

Miss Marple: 'I assure you I am quite happy' (Christie, 1962, p. 14).

Mis Nait: 'Na, nenoréčiau ilgam palikti jūsu vienos, brangute, jei kartais nusimintumète.'

Mis Marpl: 'Užtikrinu jus, esu visiškai laiminga' (Kirvaitytè, 2000, p. 14). 
In example 1, Miss Knight does not maintain social distance properly when she asymmetrically addresses Miss Marple, the elderly protagonist, as dear/brangute, which Marple does not reciprocate since they are not friends: Miss Marple is Miss Knight's employer. Overall, Miss Marple herself always addresses Miss Knight as Miss Knight (Christie, 1962), maintaining social distance. Yet social distance is maintained in the $T T$ due to symmetric use of plural second-person pronouns. This may result in the reader not grasping that Miss Knight refuses to maintain social distance, attempting to assert power and lower Miss Marple's status. In the ST, Miss Marple subtly responds by not using any address forms to appear neutral and regain social distance. Generally, Miss Knight often refers to Miss Marple as part of a stereotypical group, 'poor old dears' (Christie, 1962, p. 16), classifying Miss Marple along with other elderly women she has taken care of as senile, lacking intellectual ability and thus inferior. When speaking, Miss Knights tends 'to treat [the elderly] as slightly mentally afflicted children' (Christie, 1962, p. 15), signalling informal address forms, not expressing respect or endearment. By being presented with a polite pronoun, Lithuanian readers are put in a position in which Christie's intended effect of the subtle struggle to assert power and maintain social distance does not reach them because Miss Knight sounds polite and friendly, mismatched with her description.

In other cases, the relative status of characters also depends on their occupation and rank so that the address forms used by and for them are often governed by professionalism. The exchanges are professional, formal, and polite so that the translator, again, can intuitively use plural second-person pronouns, transferring the relationships faithfully. Nonetheless, in cases of speech between one police officer and his subordinates or superiors, the expression of power relations is very subtle, signalling the gradual decline in strict social norms, as seen in examples $2-4$ :

2. Dermot Craddock: 'I take it I'm going down there, sir' Assistant commissioner: 'Yes. Better get there as soon as possible, Dermot. [...] Good luck to you' (Christie, 1962, p. 79)

Dermotas Kredokas: 'Suprantu, kad aš ten vyksiu, sere?' Komisaro padéjèjas: 'Taip. Važiuok ten kuo greičiau, Dermotai. [...] Sèkmès tau' (Kirvaitytè, 2000, p. 75) 
3. Dermot Craddock: 'I think you'll have to banish that rosy picture from your mind, Frank'.

Frank Cornish: 'Lola Brewster is my best bet [...] You don't seem as sold on her as I am' (Christie, 1962, p. 133-135).

Dermotas Kredokas: 'Bijau, kad tau teks išmesti iš galvos šią viliojančią minti, Frenkai.'

Frenkas Kornišas: 'Itartiniausia Lola Briuster [...] Tu, rodos, nelabai tiki šia versija?' (Kirvaitytè, 2000, p. 125-127).

4. Dermot Craddock: 'Well, Tom, what have you got for me?' [...] What gold and silver have you picked for me?'

Tom Tiddler: 'Well, there were no such rumours going about at the studios' [...] You hear that sort of thing soon enough' (Christie, 1962, p. 119-120).

Dermotas Kredokas: 'Na, Tomai, ką man turi? [...] Kokiu auksiniu ir sidabriniu tu man pririnkai?'

Tomas Tidlers: 'Na, tokie gandai studijoje nesklinda, [...] Jūs išgirstumète toki dalyką pakankamai greitai' (Kirvaitytè, 2000, p. 111-112).

In example 2, an instance of faithful rendition for comparison with others, the exchange is asymmetric in both ST and TT, as Inspector Craddock addresses his superior, the assistant commissioner, as sir/sere but is addressed by his first name and a singular second-person pronoun, which indicates that his superior holds more power.

The effect that the translator creates here is of hierarchy in the workplace, which is also present in the English novel. Christie's decision to have Dermot Craddock addressed by his first name and her use of informal language signals solidarity and the wish for equality on behalf of the superior officer in this conversation. The effect that she creates is that of friendliness and mutual respect for each other. The same effect is created by the Lithuanian translator: though the reader is familiar with the requirement for officers to respect their superiors, they understand that these characters are on friendly terms due to the informality of the language used.

In other instances, the subtlety with which Christie handles the conversation and the characters' acceptance of less strict social norms is much more covert, only the absence of titles signalling friendliness. Although Inspector Craddock is of higher occupational status than Inspector Cornish because he represents Scotland Yard (Christie, 1962, p. 162), the symmetric 
use of singular second-person pronouns, as seen in example 3, indicates solidarity and equal status between the two characters in the $\Pi$. Nevertheless, Craddock is showing friendliness by addressing a local officer, Cornish, by his first name, which Cornish does not reciprocate. As a result, Craddock holds more power so that the exchange is actually asymmetric. The effect Christie creates is that by eluding the use of Craddock's first name, Cornish accepts his higher status, trying to be neutral. Cornish's use of informal language signifies a level of solidarity, but his refusal to use the first name signals his wish for social distance and uneasiness towards the decline of strict social norms. The reader may not grasp this because the conversation is made informal and Christie's intended effect is lost to some extent. The neutrality of you, as well as the omission of the address form in English makes this passage very subtle, posing difficulty to the translator as to what translation strategy to choose. The omission of second-person pronouns makes the passage more neutral in the $\pi$.

Example 4 also shows an asymmetric exchange between Craddock and his subordinate Sergeant Tiddler, also from Scotland Yard. As an officer with a superior rank, Craddock holds more power and addresses his subordinate by his first name, to which Tiddler answers by addressing him as jūs, thus recognising and completely accepting his higher status in the $\mathrm{TT}$. By saying you hear that sort of thing in the English novel, Tiddler is not addressing Craddock nor commenting on his work as an investigator; he generalises about the spread of rumours at the studios using the generic you, referring to no one in particular. In the ST, Tiddler actually evades any address forms, attempting to be as neutral as possible, though accepting Craddock's intent for solidarity, as he chooses the pronoun you instead of one, which is used to express formality and distance.

Given that Craddock is not being hostile, as his use of informal yet friendly language signals, Tiddler's neutrality in address forms marks both his uncertainty in this conversation and his understanding of the declining strictness in social norms. Here Christie creates a paradox: although Tiddler wishes for solidarity, he is afraid that too much informality on his behalf may be seen as an attempt to assert power. His only option is to maintain social distance and hint at the wish for solidarity by using you to generalise, entailing uncertainty towards the behaviour in social interactions that unfolds as 
the society transitions into informality. Christie creates not only the effect of uncertainty but also the effect of struggle to balance power relations in conversation. The translator's choice of the plural second-person pronoun shows great social distance rather than a wish for solidarity, creating an effect on the reader that the social norms are stricter than they actually are. Subsequently, the overall effect of the feeling of social transition on the reader is less emergent in the $\pi$.

In comparison, set in a different society at a different period of time, Grisham's The Pelican Brief portrays a decline in politeness in social exchanges and an increase in underlying meanings, as very often characters use the polite forms required for their status groups, but are actually being rude. Čeponis tends to use plural second-person pronouns even if the exchange is between people who are in a personal relationship or between those who are being deliberately rude to each other. This is not the case in all instances, as Čeponis also renders solidarity in exchanges between a number of characters, but he maintains formality in exchanges between characters in high positions, sometimes unnecessarily.

There are many exchanges of solidarity between the journalist Gray Grantham and people he works with, indicating that their relationships are often personal, as well as professional. When speaking with editors in the office of the Washington Post, Smith Keen and the executive editor, Jackson Feldman, Grantham and these characters are often on a first-name basis. However, in the $\pi$, they sometimes address each other using polite plural second-person pronouns and verb forms (see example 5):

5. Smith Keen: 'But they're digging, Gray'.

Gray Grantham: 'You want me to stop them?'

Jackson Feldman: 'That's a pretty damned good story, wouldn't you say, Gray?'

Smith Keen: 'You're using her, aren't you?'

Gray Grantham: 'You guys are assuming a hell of a lot'.

Jackson Feldman: 'You'd better move fast, Grantham' (Grisham, 1992, p. 289-291).

Smitas Kynas: 'Bet jie kapsto, Grèjau'.

Grèjus Grenthemas: 'Norite, kad juos sustabdyčiau?'

Džeksonas Feldmenas: 'Tai velniškai gera istorija, ar jums taip neatrodo, Gréjau?'

Smitas Kynas: 'Tu ja naudojies, tiesa? 
Grëjus Grenthemas: 'Jūs, vyručiai, spèjate labai daug'.

Džeksonas Feldmenas: 'Patariu paskubèti, Grenthemai' (Čeponis, 2004, p. 235-236).

Here, Čeponis has Grantham addressed in a variety of ways: by his first name and his last name, as well as one of these in combination with plural and singular second-person pronouns. Grantham responds with plural secondperson pronouns because he addresses all the characters as a group; therefore, it is difficult to say whether the exchanges are symmetric or asymmetric, though his address form for his colleagues guys/vyručiai indicates a feeling of solidarity among them.

Despite Čeponis's attempts to establish politeness, this conversation is highly informal, as the use of swearwords marks, suggesting a close relationship among these characters. Rather than being seen as offensive, swearing here is another means to signal solidarity. Because Keen addresses Grantham with a singular second-person pronoun while Feldman uses a plural one in Lithuanian, Grantham and Keen's relationship seems evidently closer to the reader than that of Grantham and Feldman's. Nevertheless, when addressing the editors as a group, Grantham also uses swearwords, meaning that all of them are rather close and do not see rude language as disrespectful. Čeponis's decision to use both familiar and polite second-person pronouns inconsistently affects the narrative in that it may create contingent quandary about the relationships among these characters in the readers, distancing them from the feeling of rude solidarity Grisham creates.

In comparison to these exchanges, where personal relationships militate against professional interactions, there are instances where Čeponis uses extensive formality in his translation even though the relationships are close or intimate, which is especially the case with the protagonist, Darby Shaw. Over the course of events, when Darby becomes very friendly with Gavin Verheek, who was her lover Thomas Callahan's friend and a lawyer, and later Gray Grantham, the exchanges between them are made more formal in Čeponis's translation (see examples 6 and 7):

6. Darby Shaw: 'That's pretty weak, Gavin. You've been at the office for almost four hours, and you have nothing'.

Gavin Verheek: 'Darby! Listen to me. Whatever you do, keep in touch with me, okay?' (Grisham, 1992, p. 148-149). 
Darbè Šo: 'Nieko gero, Gevinai. Buvote istaigoje beveik keturias valandas ir nieko nepešète.

Gevinas Verhekas: 'Darbe! Klausykite. Kad ir ką darytumète, palaikykite su manimi ryši, gerai?' (Čeponis, 2004, p. 125).

As seen in example 6, Darby and Gavin are in a close relationship; they are on a first-name basis and communicate in an informal context. They become close when Gavin tries to help Darby by making the legal brief she wrote public and, later, to escape assassins. Their polite exchanges in the $T T$ may sound unnatural to the reader: these characters are not only unrestricted by their occupational positions, but also share a recent and highly traumatic experience, the death of Gavin's oldest friend and Darby's lover, Callahan. This brings them close to each other, so that their exchanges are made unnecessarily formal in the $\pi$, slightly distorting the relationship and thus creating a barrier between the reader and the original novel.

The same problem occurs when Čeponis is translating exchanges between Grantham and Darby, as seen in example 7. They are also on a firstname basis, indicating growing intimacy between them. From the very onset, Darby contacts Grantham offering an unofficial deal: he wants information for his story; she wants to make her brief public (Grisham, 1992, p. 130). From then on they meet in secret and work as partners, with Grantham occasionally referring to his attraction towards Darby and Darby responding with sarcasm. Moreover, before the exchange in example 7 they are said to be holding hands (Grisham, 1992, p. 392), which indicates that they are becoming romantically involved.

7. Darby Shaw: 'Gray, come here, please. [...] Watch him carefully'

Gray Grantham: 'What're you saying, Darby?' (Grisham, 1992, p. 394).

Darbè Šo: 'Grejjau, prašau ateiti čionai. [...] Stebékite ji atidžiai'

Grèjus Grenthemas: 'Ką norite pasakyti, Darbe?' (Čeponis, 2004, p. 318-319).

Considering the intimacy between them, their exchanges in Lithuanian sound unnatural, even more so than the exchanges between Gavin and Darby. 
Čeponis creates a paradox: although exchanges between Darby and Gavin or Grantham are those of solidarity and closeness in the ST, Čeponis's use of the plural second-person pronoun indicates distance, which is no longer present at this stage in the English narrative. Čeponis's attempts to separate the characters' feelings from their work by using polite pronouns does not match the overall description Grisham presents about their intimate relationship.

The reader is alienated from the actual development of the overt romantic relationship, one of the defining features of legal thrillers (Danytè, 2011, p. 38), in conversation. Again, the readers are put in a position where they are left to decipher the graduate development of this relationship based on the descriptions of Grantham and Darby's behaviour. Therefore, Čeponis creates another salient instance of dissonance; in this case, it is between these characters' actions and the language used in the $T$. Whereas their behaviour signals intimacy, their language in the TT marks social distance. The reader is presented with a delay in Grantham and Darby's romantic relationship in the $\Pi$, which makes their conversations sound rather awkward when the context in which they occur proclaim intimacy between them. The outcome of such delay and dissonance is the distortion of Grantham and Darby's romantic relationship, which not only affects the plot, but also creates a barrier between the reader and the original.

Čeponis (2004, p. 351) uses familiar pronouns only in the last chapter of the novel, when Darby invites Grantham to stay with her. This creates a sudden jump from formality to informality, even though in the English ST this shift from allies to intimate friends takes place more gradually with their decision to use first names. Again, provided that translation is a subjective process, and that Čeponis belongs to an older generation (born 1935), his choice to have Darby addressed as jūs most of the time conforms to the norms of conversation between older men and women at the end of the twentieth century in Lithuania. The issue that arises here is that in many conversations the translator follows more conservative norms acceptable to his age group in 1990s, even though the male characters are not much older than Darby and thus less conservative. To preserve the social norms acceptable to him, Čeponis compromises Grisham's intention to depict an informal society and some genre conventions like overt romantic relationships, distancing the reader from the reality of the novel. 
Another and possibly the most important instance in which Čeponis does not fully transfer Grisham's intentions appears in the exchanges among characters in very high positions. While one would expect people in high positions to be formally polite, as required by their high status, Grisham portrays these people satirically, so that their language is very often discordant with their status. Even if these characters continue to use polite titles, their language is often extremely rude and even vulgar, as seen in example 8.

8. Bob Gminski: 'Come on! Are you serious, Mr. President!' The President: 'Check it out, Bob.' (Grisham, 1992, p. 41).

Bobas Gminskis: 'Liaukitès! Nejau jūs rimtai, pone prezidente?!'

Prezidentas: 'Patikrinkite tai, Bobai' (Čeponis, 2004, p. 39).

This example is from exchanges among the President of the United States, his chief of staff, Fletcher Coal, the head of the FBI, Denton F. Voyles, and the head of the CIA, Bob Gminski. Example 8 shows that the President often addresses his inferiors by their first names, which indicates that his status is the highest, but also that he likes to emphasise this so that he is rather disrespectful towards them. For example, he often expresses his dislike towards Voyles and plans to humiliate him publically, imagining his power over the head of the FBI: 'I'll take Voyles with me, but I'll keep his mouth shut. Make him stand behind me. [...] Networks'll carry it live, don't you think?' (Grisham, 1992, p. 50).

The President himself is addressed politely with a title in example 8, which also expresses his superiority. Čeponis chooses to use the plural secondperson pronouns and verbs to make these exchanges sound formal to reflect these characters' high status, regardless of them often being rude. Following the norms of politeness in the target culture, Čeponis disregards Grisham's intention to portray high status characters satirically with their vulgar language, which is similar to the vulgar language used by Richard Nixon, the President of the United States, in his secret tapes in the 1970s (Little, 2018). Possibly fearing to contradict the norms of the target culture, Čeponis again compromises Grisham's intentions and genre conventions.

Furthermore, the relations between Coal and Voyles are not only rude but openly hostile; their social interactions are dictated by their wish to insult 
one another. As seen in examples 9 and 10, they insult and accuse each other and are deliberately rude.

9. Denton F. Voyles: 'In fact, I was here when you were running around in dirty diapers, Mr. Coal'.

Fletcher Coal: 'I think you've had leaks yourself' (Grisham, 1992, p. 55).

Dentonas F. Voilzas: 'Iš tiesu, lankiausi čia, kai jūs dar lakstète su nešvariais vystyklais, pone Koulai'.

Flečeris Koulas: 'Man regis, nutekèdavo ir iš jūsu paties' (Čeponis, 2004, p. 49).

10. Denton F. Voyles: 'You're an idiot, Coal! [...] It doesn't work that way, son'.

Fletcher Coal: 'You bust your ass to make sure these names are kept out of the papers until they're nominated'.

Denton F. Voyles: 'Listen, asshole, you want them checked out, you do it yourself' (Grisham, 1992, p. 85).

Dentonas F. Voilzas: 'Jūs idiotas, Koulai. [...] Šitaip nepavyks, sūnau'.

Flečeris Koulas: 'Persipléškite subinę, bet pasirūpinkite, kad tos pavardès nepatektu i laikraščius, kol nebus patvirtintos'.

Dentonas F. Voilzas: 'Klausykite, šikniau, jei norite, kad jie būtu patikrinti, imkitès to pats' (Čeponis, 2004, p. 73).

Their language not only does not coincide with their high social status, it is highly pejorative, with terms like idiot and asshole being used. These characters deliberately try to make each other feel inferior and assert their power; therefore, these exchanges are not supposed to be formal. Čeponis faithfully translates all the rude address forms but does not use matching singular second-person pronouns and verbs. This affects the narrative by making open hostility milder due to the use of polite pronouns, resulting in awkward conversations.

Rudeness in these instances is by no means covert; unlike Christie, Grisham does not approach decay in social norms with subtlety. He ostensibly emphasises the dissonance between one's high status and the language used. Having his characters be overtly rude, he creates the effect of shock in the readers who possibly do not expect the highest ranks of society to be vulgar and immoral or act in other ways contradictory to their high status. Whilst for these characters vulgarity and rudeness are means of asserting power and 
demeaning social distance, Čeponis's use of polite second-person pronouns has the opposite effect. By using them, he reinforces social distance, diminishing the attempts to assert power. Instead of being shocked, the readers are put in a position where they may face quandary stemming from a rather awkward rendition of rude exchanges.

\section{Conclusions}

The analysis of selected instances of social interactions has indicated that through their use of familiar and polite second-person pronouns Rasa Kirvaityte and Jonas Čeponis often do not fully mediate the effects Agatha Christie and John Grisham intended on their readers. In The Mirror Crack'd from Side to Side, Christie creates three types of effects on the reader: (1) the struggle to balance power relations and social distance; (2) uncertainty towards the behaviour in social interactions that unfolds due to the decline in strict social norms; (3) overall subtlety in social transition. Contrary, these effects do not always reach the Lithuanian readers, as the effects Kirvaitytè's translation has on them operate on the opposite side of the subtlety spectrum: in some cases, social transition is less emergent and social norms seem to be stricter than in the English novel, in others the subtlety with which Christie depicts the transition is lost.

In The Pelican Brief, though both Grisham and Čeponis create the effect of dissonance on the reader, it is completely different. Whereas Grisham creates dissonance between the characters' high status and the rude language used, Čeponis creates dissonance between these characters' behaviour and their language. When characters openly express hostility and their attempts to assert power or when they display intimacy, Čeponis aims to reinforce politeness by using polite second-person pronouns to conform to Lithuanian social norms acceptable to his age group, which is discordant with the overall informal awkwardness in the Lithuanian reader when Grisham intended to induce shock. Moreover, using polite language present in the novel. Consequently, this may evoke the feelings of quandary, confusion, and secondperson pronouns, Čeponis creates another effect on the readers, which is 
absent in the original novel: the Lithuanian reader faces a delay in or distortion of intimate relationships.

Similarly, to other studies (Boyden, 2014; Khakimova, 2017), this study has shown that sometimes the translator does not act as a mediator but rather affects the reader's perception of the original novel. The present study sees some of the translators' impact as the creation of a barrier between the reader and the original narrative because the effects intended by the writers are not rendered faithfully. The result of the translators' choices is evident: the two novels selected for this study served as examples of translations that may put the reader in an uncomfortable position. They present the reader with a degree of quandary, confusion, and awkwardness, evoking dissonance and alienating them from the original narratives. To avoid instances like this, it is necessary for translators to not only carefully consider genre conventions, sociocultural and sociolinguistic theories in source and target cultures, and the contexts of literary works and their writers, but also consider whether the application of social norms of the target culture in the $\pi$ would not interfere with the writers' intentions, so that the representation of the societies depicted would be mediated faithfully.

\section{References}

Allan, K., \& Burridge, K. (2006). Forbidden Words: Taboo and the Censoring of Language. Cambridge: Cambridge UP.

Anderman, G. M. (1993). Untranslatability: The Case of Pronouns of Address in Literature. Perspectives: Studies in Translatology, 1, 57-67.

Boyden, M. (2014). Voiceless Ends: Melville's Benito Cereno and the Translator in Narrative Discourse. Language and Literature, 23(3), 255-269. doi: 10.1177/0963947014536506.

Brown, R., \& Gilman, A. (1960). The Pronouns of Power and Solidarity. In T. A. Sebeok (Ed) Style in Language (pp. 253-276). Cambridge: MIT.

Chan, T. W, \& Goldthorpe, J. H. (2007). Social Status and Newspaper Readership. American Journal of Sociology, 112(4), 1095-1134. doi: $10.1086 / 508792$

Christie, A. (1962). The Mirror Crack'd from Side to Side. London: Collins. 
Kirvaitytè, R. (2000). Perskilęs Veidrodis. Translation of Agatha Christie's The Mirror Crack'd from Side to Side. Vilnius: Sirokas.

Cook, M. (2014). Beyond T and V - Theoretical Reflections on the Analysis of Forms of Address. American Journal of Linguistics, 3(1), 17-26.

Čeponis, J. (2004). Pelikano dosjè. Translation of John Grisham's The Pelican Brief. Kaunas: Jotema.

Čubajevaitè, L. (2006). Cultural and Linguistic Differences in Using Personal Pronouns: Case of Lithuanian as a Foreign Language. Kalbotyra, 56(3), 33-38.

Danytè, M. (2011). Introduction to the Analysis of Crime Fiction. Kaunas: Vytautas Magnus University.

Danytè, M. (2012). Thematic Shifts in Crime Fiction: How American Thrillers Engage with Social Issues at the Turn of the Century. In R. Rudaitytè (Ed) Literature in Society (pp. 208-226). Newcastle: Cambridge Scholars.

Drazdauskienè, R. (2016). Koks buržujis, toks ir menas: trumpai apie užsienio detektyvu vertimus i lietuviu kalba. Knygu aidai, 4. Retrieved from https://www.Ilvs.It/?recensions=221.

Dziedravičiūtè, N. (2009). Translation Problems for Lithuanian Translators Raised by English Dysphemistic Forms of Address: The Example of J. D. Salinger's The Catcher in the Rye. In F. Popescu (Ed) Perspectives in Translation Studies (pp. 54-70). Newcastle upon Tyne: Cambridge Scholars.

Ermida, I. (2006). Linguistic Mechanisms of Power in Nineteen Eighty-Four: Applying Politeness Theory to Orwell's World. Journal of Pragmatics, 38, 842-862. doi: 10.1016/j.pragma.2005.05.008.

Girčienè, J. (2011). Adresato Ivardijimo Raida. Žmogus Kalbos Erdvèje, 6, 18. Retrieved from http://www.sociolingvistika.It/failai/ Girciene_Adresato\%20ivadijimo\%20raida_In_Zmogus\%20kalbos\%20 erdveje\%207,\%202013,\%20613-621.pdf.

Grisham, J. (1992). The Pelican Brief. New York: Bantam Doubleday Dell. Khakimova, S. R. (2017). Dissonting Problems in Literary Translation. Arts and Social Sciences Journal, 8(4), 292-296. doi: 10.4172/21516200.1000292. 
Little, B. (2018). 7 Revealing Nixon Quotes from His Secret Tapes. History. Retrieved from https://www.history.com/news/nixon-secret-tapesquotes-scandal-watergate.

Millner, M. Jr. (2010). Status Distinction and Boundaries. In J. R. Hall, L. Grindstaff and M. C. Lo (Eds) Handbook of Cultural Sociology (pp. 295-304). New York and London: Routledge.

Nunez, K. J. (2012). Literary Translation as an Act of Mediation Between Author and Reader. Estudios de Traducción, 2, 21-31. doi: 10.5209/rev_ESTR.2012.v2.38975.

Ridgeway, Cecilia L. 2014. Why Status Matters for Inequality. American Sociological Review, 79(1), 1-16. doi: 10.1177/0003122413515997.

Strümper-Krobb, S. (2003). The Translator in Fiction. Language and Intercultural Communication, 3(2), 115-121.

Shirinzadeh, S. A., \& Mahadib, T. S. T. (2015). Translators as Cultural Mediators in Transmitting Cultural Differences. Social and Behavioral Sciences 208, 167-174. doi: 10.1016/j.sbspro.2015.11.193.

Robson, D. (2016). How Important Is Social Class in Britain Today? BBC Future. Retrieved from http://www.bbc.com/future/story/20160406-howmuch-does-social-class-matter-in-britain-today.

Rosinas, A. (1996). Lietuviu Bendrinès Kalbos Ivardžiai. Funkcijos ir Semantika. Vilnius: Mokslo ir Enciklopediju Leidykla.

Thornborrow, J. (2004). Language and Identity. In I. Singh and J. Stilwell Peccei (Eds) Language, Society and Power: An Introduction (pp. 157173). $2^{\text {nd }}$ ed. London: Routledge.

Venuti, L. (1995). The Translator's Invisibility. London: Routledge.

Yang, X. (2010). Address Forms of English: Rules and Variations. Journal of Language Teaching and Research, 1(5), 743-745. 


\author{
Gintarè Pavilavičiūtè \\ Vytauto Didžiojo universitetas, Lietuva \\ gintare.pavilaviciute@gmail.com
}

\title{
VERTIMAS KAIP BARJERAS TARP ORIGINALAUS KŪRINIO IR SKAITYTOJO: GALIOS SANTYKIU IR KREIPINIU DVEJUOSE DETEKTYVINIUOSE ROMANUOSE TYRIMAS
}

\begin{abstract}
Santrauka. Nors nuo dvidešimtojo amžiaus pabaigos literatūros vertèjas dažnai yra aptariamas kaip tarpininkas tarp autoriaus ir kitataučio skaitytojo, naujesniuose tyrimuose atskleidžiama, kad vietoj tarpininkavimo, vertèjas kartais savaip paveikia verčiama teksta. Todèl tyrimu dèmesys dabar krypsta nuo vertèjo link skaitytojo. Šiame straipsnyje siekiama ištirti galima vertejo sukurta poveiki, kuri skaitytojas jaučia skaitydamas literatūrinio kūrinio vertima, o ne originala. Tam atskleisti, kaip tyrimo objektas pasirinkti kreipiniu kaip socialinès padèties žymejjimo vertimas i lietuviu kalbą bei atitinkamy antrojo asmens mandagiu ar familiariu ivardžiu derinimas Agatos Kristi Perskilęs veidrodis (1962) ir Džono Grišemo Pelikano dosjè (1992) detektyviniuose romanuose. Versdamas literatūra, vertèjas dažnai susiduria su kultūriniais skirtumais, esančiais tarp rašytojo ir skaitytojo visuomeniu. Būtent dèl savo detaliu bei realistišku autoriaus pasirinktos kultūros ir socialiniu normu aprašymu detektyviniai romanai vertejams gali sukelti sunkumu, kai norima teisingai perteikti galios santykius tarp veikejju pasitelkus tinkamas antrojo asmens ivardžiu formas, kuriu anglu kalboje - tik viena. Šiame tyrime išsiaiškinta, kad vertejas kartais neteisingai supranta galios santykius arba teikia pirmenybę savo kultūros socialinèms normoms, šitaip paveikdamas kūrini ir sukurdamas poveiki, neatitinkanti originalo autoriaus siekiu. Kai kuriais atvejais šitaip net sukuriamas barjeras tarp skaitytojo ir originalaus literatūrinio kūrinio.
\end{abstract}

Pagrindinès sąvokos: galios santykiai; kreipiniai; literatūrinis vertimas; vertimo poveikis; barjeras. 